\title{
E. coli and Coliform Bacteria as Indicators for Drinking Water Quality and Handling of Drinking Water in the Sagarmatha National Park, Nepal
}

\author{
Kirsten Ngaire Nicholson (Corresponding author) \\ Department of Geological Sciences, Ball State University, Muncie Indiana USA \\ Tel: 1-765-285-8270Ｅ-mail: knichols@bsu.edu
}

Klaus Neumann

Department of Geological Sciences, Ball State University, Muncie Indiana USA

Tel: 1-765-285-8270Ｅ-mail: kneumann@bsu.edu

\section{Carolyn Dowling}

Department of Geological Sciences, Ball State University, Muncie Indiana USA

Tel: 1-765-285-8270Ｅ-mail: cbdowling@bsu.edu

\begin{abstract}
Subodh Sharma
Department of Environmental Science \& Engineering, Kathmandu University, Nepal E-mail: subodh.sharma@ku.edu.np
\end{abstract}

Received: September 8, 2017 Accepted: September 23, 2017

doi:10.5296/emsd.v6i2.11982ＵRL: https://doi.org/10.5296/emsd.v6i2.11982

\begin{abstract}
During the 2016 pre-monsoon dry season, we undertook a systematic study of water quality, specifically fecal contamination of drinking water, in the Khumbu Valley, Sagarmatha National Park (SNP, Mt. Everest region) and SNP buffer zone, Nepal. Our goal was to quantify physical parameters (temperature, $\mathrm{pH}$, conductivity and total dissolved solids), and the presence of fecal coliforms (E. coli and total coliforms) in drinking water and drinking
\end{abstract}


water sources (predominately groundwater-fed springs). This data set will function as a baseline for access to potable water and further monitoring. Sample sites were selected based on primary use as a drinking water and/or drinking water source for each community.

In general, there is little correlation between and physical parameters however, there are very weak correlations between total coliform data and increasing temperature, and decreasing elevation and $\mathrm{pH}$. There does, however, appear to be a correlation between population (including tourist numbers) and both E. coli and total coliforms.

Our study clearly indicates that the presence of bacterial indicators of fecal pollution during the dry season. Samples from the more populated, lower altitude areas had higher levels of E. coli and coliform bacteria. Importantly, drinking water that was stored in tanks or transported long distances had a much higher incidence of E. coli and total coliforms suggesting that a change in water handling practices might have an important impact on drinking water quality and population health.

Keywords: Fecal coliform, E. coli, Mt. Everest, Sagarmatha, Drinking water quality, Baseline dataset

\section{Introduction}

The southern slopes of Mt. Everest are situated in the Sagarmatha National Park (SNP; Figure 1), which are part of the Nepali Himalaya: between $27^{\circ} 30^{\prime} 19^{\prime \prime} \mathrm{N}$ to $27^{\circ} 06^{\prime} 45^{\prime \prime} \mathrm{N}$ latitude to $86^{\circ} 30^{\prime} 53^{\prime \prime E}$ to $86^{\circ} 99^{\prime} 08^{\prime \prime E}$ longitude, and covers $1148 \mathrm{sq} \mathrm{km}$ area. The SNP has been a national park since 1976 and became a World Natural Heritage Site in 1979. A buffer area $(\sim 275 \mathrm{sq} \mathrm{km})$ was created in 2002 to enhance the protection of the World Natural Heritage Site and is known at SNP Buffer Zone. The Himalayan Mountains form the main headwaters for major river systems, such as the Ganges, Yangtze and Indus (Balestrini et al 2014), which are the source of water for over a billion people, hence understanding all aspects of the hydrologic cycle is important. 


\section{Macrothink}

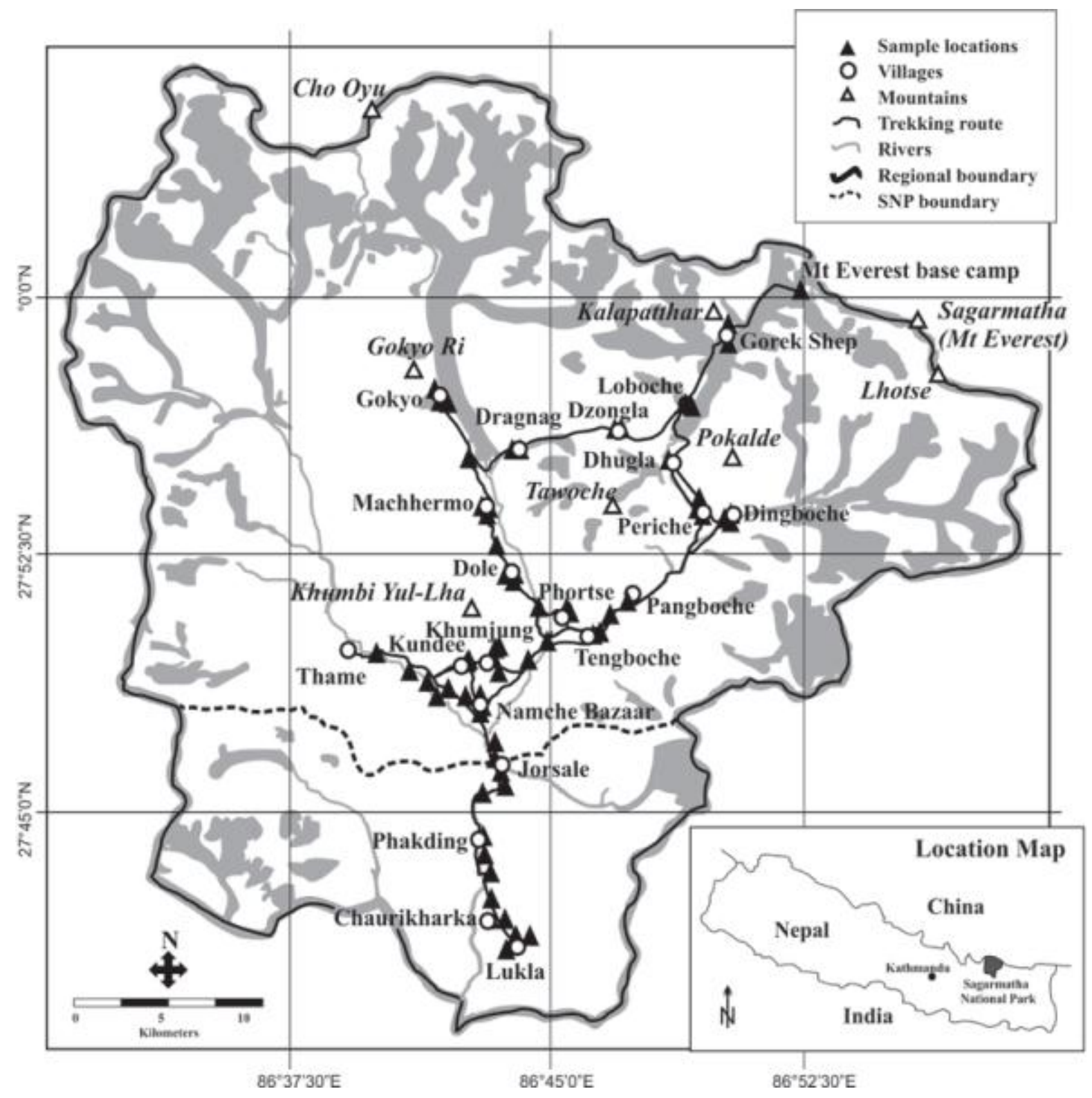

Figure 1. Location map showing the samples collected in 2016 within the SNP and the SNP Buffer Zone

The SNP, particularly the trekking route to Mt. Everest, is a prime destination for international tourists and their accompanying porters and guides (Salerno et al. 2010a, 2010b). Since the first ascent on Mt. Everest in 1953, the annual number of tourists to visit the region has risen from less than 20 people per year, to well over 30,000 tourists per year. Similar to many protected areas around the globe, tourism is the primary source of local income, and as such has been extensively promoted (WTO, 2005; Salerno et al. 2013), prompting the World Tourism Organization (2005) to declare that "tourism operations in protected areas need to be carefully planned, managed and monitored to ensure their long-term sustainability" (WTO, 2005).

In the SNP, the increasing tourist numbers has resulted in wide spread anthropogenic problems associated with human waste (Ghimire et al. 2013a). Along the major trekking 
routes it is possible to see the environmental impacts of improper disposal of non-biodegradable solid waste, such as water bottles, plastic bags, batteries etc., strewn along the trails. The combination of poorly managed or unmanaged disposal of solid waste with open defecation has resulted in considerable environmental degradation of major rivers in the region (Ghimire et al. 2013). In some villages it is possible to see sewage and toilet waste piped directly into nearby streams and rivers (Carovello et al. 2007). Despite the pollution, drinking water is still sourced from surface water in some places.

Although there have been several studies of fecal contamination of drinking water in the Kathmandu Valley which is roughly 200km to the east-southeast (Karkley et al. 2016 and references therein), there are few studies of fecal contamination of drinking water in the SNP nor are there studies characterizing the shallow groundwater springs which are used for drinking water. Preliminary work by Ghimire et al. (2013) and Nicholson et al (2016) suggests that fecal contamination may be a significant problem throughout the region, yet drinking water is rarely treated prior to use.

Fecal contamination poses significant danger to human health (Okpokwasili and Akujobi 1996), however, the presence of coliform bacteria can be used as an indicator for fecal contamination of water and, hence, of potential health risks (Okpokwasili and Akujobi 1996). There are a number of pathogenic microorganisms that can be transmitted to humans through water contaminated with fecal matter such as: enteropathogenic agents (i.e. salmonella, shigella) enteroviruses, multicellular parasites and opportunistic pathogens such as Pseudomonas aeruginosa, Klebsiella, Vibrio parahaemolyticus and Aeromonas hydrophila (Hodegkiss 1988). However, isolating and identifying these organisms can be complicated, expensive and is rarely quantitative (Cairneross et al. 1980; WHO 1983). Fortunately, measuring coliform bacteria (total coliform bacteria and/or fecal coliforms (in this case E. coli)) represents an indirect approach to measuring fecal contamination based on the assumption that these normal enteric organisms will indicate the level of fecal contamination of the water supply (WHO 1983; Pathak and Gopal, 2001; Harwood et al. 2001; Vaidya et al. 2001; Kistemann et al. 2002). When combined with other indicators such as the physical characteristics of the water as well as distribution and access to water, the presence of bacteria can be used to help identify the reasons behind the contamination.

The goal of this study is to characterize and monitor drinking water quality, in the SNP and SNP Buffer Zone, using both physical parameters, and coliform bacteria and E. coli as indicators of fecal contamination, which may help the improve access to potable drinking water. The data are then used to ascertain possible relationships between contamination, population and altitude. Additionally, the results from this investigation can provide a baseline for further monitoring. This study is necessary along the route to Mt. Everest base camp, and throughout the SNP, because the increasing number of tourists is causing significant, unchecked, environmental degradation (Carovello et al. 2007; Ghimire et al. 2013a). 


\section{Methods}

\subsection{Location}

The 2016 study follows the main trekking routes within the SNP; starting in the township of Lukla, heading both north and upwards to Mt. Everest base camp (EBC), then crosses to Gokyo and drops back down to Lukla (Figure 1). High altitudes and rugged topography characterize the study area. Both resident and tourist populations are highest at the lower elevations: from Khumjung downwards to Lukla. The elevation of townships and communities in the SNP watersheds ranges from $2610 \mathrm{~m}$ (Phakding) to over $5000 \mathrm{~m}$ at EBC. The largest communities in the SNP are Namche Bazaar (population >1600), and the combined townships of Khumjung and Kundee (combined population >1800). Within the SNP buffer zone, the largest communities are Lukla (population >230) and Charikarka (population >2400) (Central Bureau of Statistics, 2001).

In general, the SNP experiences a temperate climate that has clear seasonality and is characterized by warm summers and cold winters. Maximum rainfall generally occurs between June and September and coincides with the Indian Monsoon. At lower altitudes, such as Lukla, the average annual precipitation is approximately $1800 \mathrm{~mm}$ and summer temperatures can reach highs of $37^{\circ} \mathrm{C}$. In contrast, the maximum altitude of the study area, at $\mathrm{EBC}$, experiences an average annual precipitation of approximately $450 \mathrm{~mm}$ and winter temperatures can reach lows of $-17^{\circ} \mathrm{C}$.

\subsection{Sampling}

Communities along the main trekking routes in the SNP and SNP buffer zone were surveyed for suitable sample sites. Sampling was completed in late April and early May 2016 prior to the onset of the monsoon season in order to minimize surface water contamination of shallow drinking water sources. Sites were selected based on the availability of the water for local and tourist use for drinking water. The number of samples collected is roughly proportional to the number of people with access to water in each township, i.e. the more residents and tourists in a location, more samples were taken. Samples were taken from 45 different localities, of these samples, 38 were from community drinking water standpipes and/or household drinking water supplies (transported water) and 7 samples were from community drinking water sources (generally groundwater-fed springs except where otherwise noted in the discussion). In this study "transported water" refers to water that is brought via tubing from springs at higher elevations and water physically carried to the location from a standpipe or community water supply. In each of the larger townships, we tested the community drinking water source. Source water was tested at the point where people first began accessing the water for drinking: these samples are referred to as "community drinking water sources". The major rivers and streams were omitted as they previously have been studied in detail (Ghimire et al. 2013) and are rarely used as a potable water source.

The highest daily air temperatures during sampling days ranged from Lukla at $15^{\circ} \mathrm{C}$ to $2{ }^{\circ} \mathrm{C}$ in Gorek Shep. 


\subsection{Bacterial Analyses and Physical Parameters}

Due to the remote nature of the study area, with no road access, no power, high altitudes and severe weather, standard E. coli sampling methods were modified (Gruver et al., 2017). Samples for bacteria analyses were collected in sterile $60 \mathrm{~mL}$ syringes and immediately passed through a push filter, using a sterile 0.45 micron filter, to total $100 \mathrm{ml}$ of sample. When it was not possible to filter the samples directly at the site, samples were collected in sterile $100 \mathrm{~mL}$ Whirl-pak bags containing a non-nutritive pill with $10 \mathrm{mg}$ sodium thiosulfate and kept below $20^{\circ} \mathrm{C}$ prior to filtration. All samples were filtered within two hours of collection. After filtration, the filter paper was placed on a sterile test card (EasyCard ${ }^{\mathrm{TM}}$ manufactured by Micrology Laboratories LLC) containing a growth medium that includes color-producing enzyme substrates specific for the target organisms ( $E$. coli and other coliforms), such that these organisms grow as differently colored colonies that are easily differentiated. The samples were then placed into a portable field incubator and kept between $20^{\circ} \mathrm{C}$ and $35^{\circ} \mathrm{C}$ for 24-48 hours. Sample counts were done using a 10x hand lens where E. coli colonies were royal blue/purple and coliform bacteria colonies appeared to be light green. Two people counted bacteria samples, and duplicate samples were run in multiple locations to ensure quality of analyses. The results were expressed as colony forming units (cfu) per unit sample volume $(100 \mathrm{~mL})$. Temperature, $\mathrm{pH}$, conductivity and TDS were measured in the field using a FisherSci Ap85 pH/conductivity meter. Physical parameters were not measured in samples collected in Whirl-pak bags.

\section{Results}

Sampling in 2016 took place during a long dry period as such many smaller springs were completely dry. Note that the township of Chaurikarka was not sampled due to torrential rain that caused surface water contamination of drinking water supplies on the days that we planned to sample.

\subsection{Physical Parameters}

The 2011 WHO (World Health Organization) guidelines for drinking water suggest that potable water should contain less than $600 \mathrm{mg} / \mathrm{L}$ (which is roughly the same as $600 \mathrm{ppm}$ ) total dissolved solids (TDS). WHO 2011 guidelines for $\mathrm{pH}$ in drinking water states that $\mathrm{pH}$ should not exceed 8 , and that values under 4 may be associated with health problems and corrosion of infrastructure.

3.1.1 Transported Water: Community Standpipes, Teahouse, and Household Drinking Water Samples

Thirty-eight individual samples were taken from community standpipes and household (generally tea houses/lodges) drinking water supplies. All sample sites were well-used drinking water sites, with a range between individual households and large teahouses/restaurants serving several hundred people. All sample sites involved water that was transported from the source to the sample location. Transportation distances ranged from hundreds of meters to longer distances (several kms) using hoses. In most locations, the water was also stored in plastic holding tanks, both at the source (to ensure continuous flow) and 
again at the end point, prior to use (i.e. in the household or kitchen). In a few smaller townships, water was carried by hand using plastic buckets to the end point.
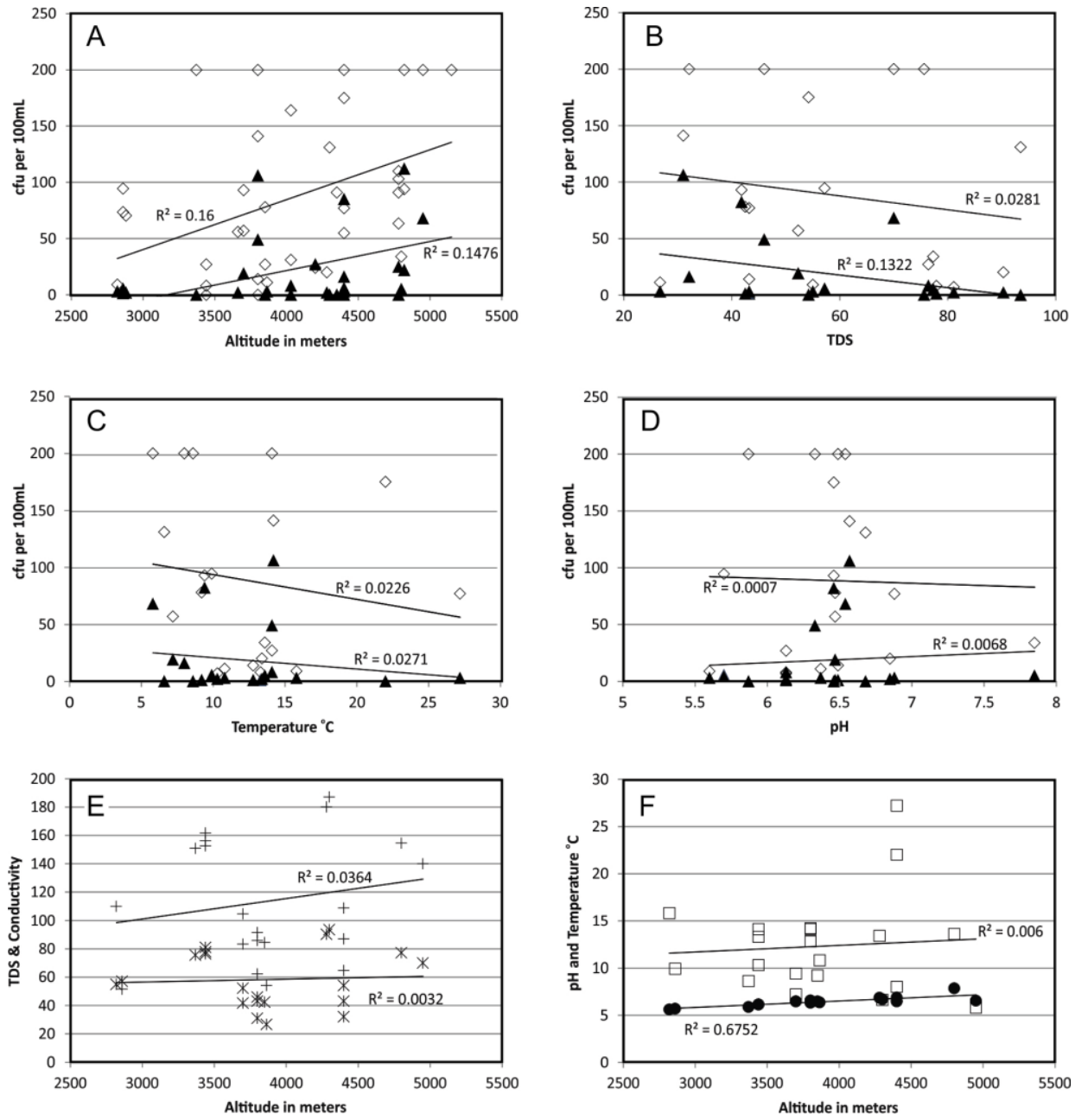

Figure 2. Bivariate plots for transported water including community standpipes and household drinking water. Plots A-D: Open diamonds: total coliform counts, Solid triangles:

E. coli counts. Plots E-F: Star: total dissolved solids, Cross: conductivity, Open squares: temperature, Solid circles: $\mathrm{pH}$.

Drinking water temperatures ranged between $5.8^{\circ} \mathrm{C}$ and $27.2{ }^{\circ} \mathrm{C}$ with an average of 12.6 $( \pm 5.0){ }^{\circ} \mathrm{C}$ (Figure $2 \mathrm{C}$ ). As expected, the temperatures decreased with increasing altitude such that the coldest drinking water was at the highest altitude townships. The warmest temperatures recorded were taken from water that had been transported using a black hose for long distances. The $\mathrm{pH}$ values for drinking water ranged between 5.6 and 7.85 with an average of $6.5( \pm 0.5)$ (Figure 2). The ranges in TDS and conductivity (Figure 2) in the samples were relatively small. The TDS average was $57.9( \pm 20.2) \mathrm{ppm}$, with a range between $26.7 \mathrm{ppm}$ and $93.5 \mathrm{ppm}$, whereas average values for conductivity was $113.0( \pm 42.5) \mu \mathrm{S}$ with a range between $51.5 \mu \mathrm{S}$ and $187.2 \mu \mathrm{S}$ (Figure 2). Figure 2 indicates that the samples show a weak negative correlation between altitude and TDS, and a very weak positive correlation 


\section{Macrothink

between altitude and temperature and $\mathrm{pH}$.

\subsubsection{Community Drinking Water Sources}

Seven individual samples were collected from the community drinking water sources in Lukla, Namche Bazaar, Khumjung, Dinboche, Gorek Shep, Gokyo and Phorche. Two samples were collected for Gokyo, Namche Bazaar, and Phorche. These sources are generally groundwater-fed springs except in a few instances where communities rely on a mixture of springs and surface water. All samples were taken directly from the town or village main drinking water source, i.e. the location where people first access the water for use. Again, all sample sites were known and well-used drinking water sources.

Drinking water source temperatures ranged between $6.9{ }^{\circ} \mathrm{C}$ and $14.1^{\circ} \mathrm{C}$ with an average of $9.8( \pm 2.7){ }^{\circ} \mathrm{C}$ (Figure 3). As expected, the temperatures decreased with increasing altitude such that the coldest drinking water was at the highest altitude townships (Figure 4). The $\mathrm{pH}$ values for drinking water sources ranged between 5.67 and 7.81 with an average of $6.5( \pm 0.7)$ (Figure 3). The ranges in TDS and conductivity in the samples were again relatively small (Figure 3). The average TDS was $62.3( \pm 16.8) \mathrm{ppm}$, with a range between $34.8 \mathrm{ppm}$ and 83.4 ppm, whereas average values for conductivity was $124.1( \pm 33.6) \mu \mathrm{S}$ with a range between $69.3 \mu \mathrm{S}$ and $166.8 \mu \mathrm{S}$. Figure 3 indicates that the non-transported drinking water samples show a weak negative correlation between altitude and temperature, a positive correlation between altitude and $\mathrm{pH}$, and there appears to be no correlation between altitude and conductivity and TDS. 

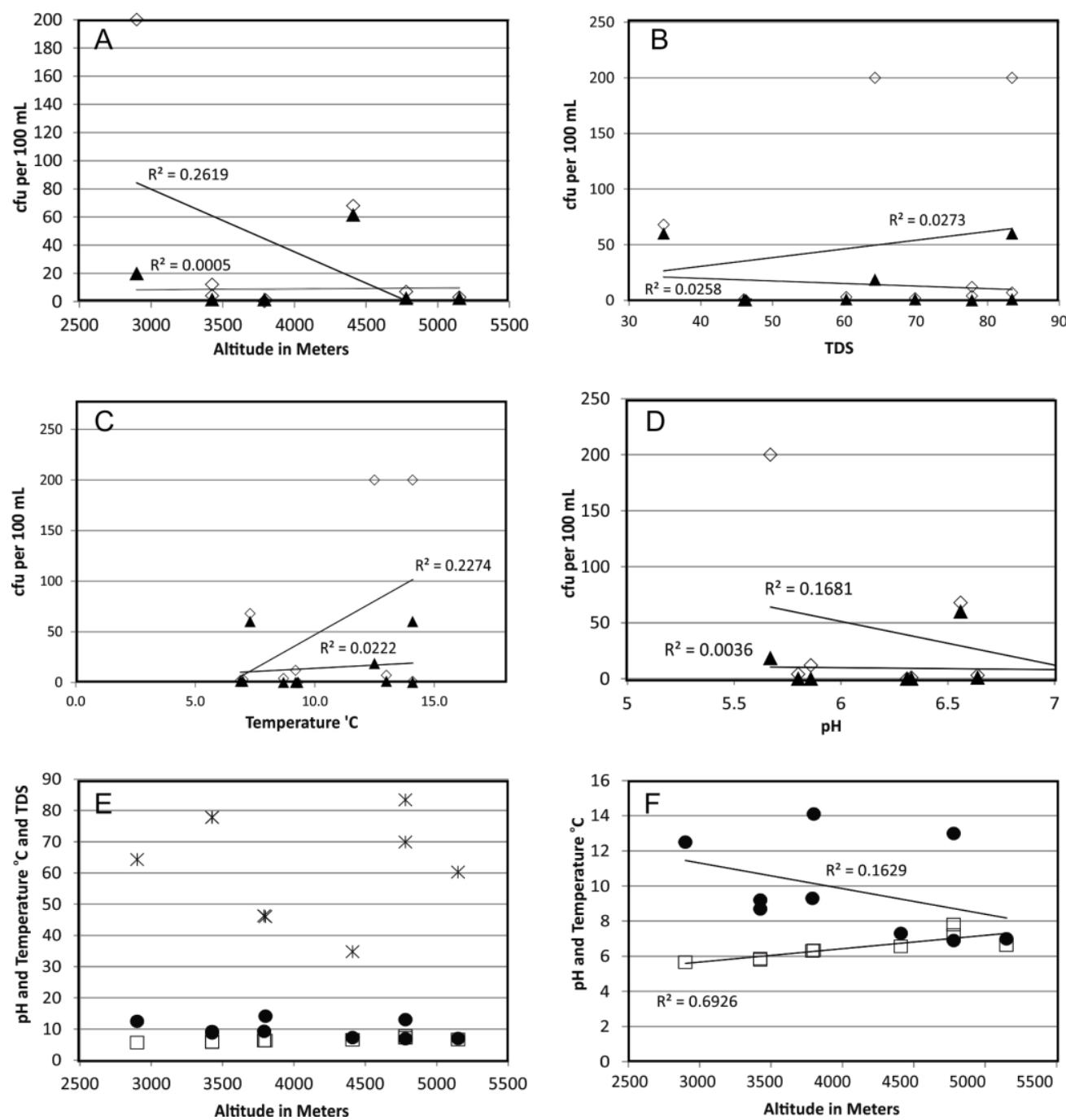

Figure 3. Bivariate plots for community drinking water sources. Plots A-D: Open diamonds: total coliform counts, Solid triangles: E. coli counts. Plots E-F: Star: total dissolved solids, Open squares: $\mathrm{pH}$, Solid circles: temperature

\subsection{E. coli and Coliform Bacteria}

The 2011 WHO guidelines for drinking water give a tolerance range for E. coli in drinking water. Although it is preferable that drinking water contain no E. coli, samples containing fewer than $10 \mathrm{E}$. coli colonies per $100 \mathrm{~mL}$ sample are considered low risk. For the purpose of this study counts that exceeded 200 were capped at 200 as counting error increased significantly.

Table 1. WHO (2011) classification and color-code scheme for E. coli colonies per $100 \mathrm{~mL}$ water sample

\begin{tabular}{|c|c|c|c|c|c|}
\hline Color & Blue & Green & Yellow & Orange & Red \\
\hline Risk level & In Conformity & Low Risk & Intermediate Risk & High Risk & Very High Risk \\
\hline \# of colonies & 0 & $1-10$ & $10-100$ & $100-1000$ & $>1000$ \\
\hline
\end{tabular}




\section{$\triangle$ Macrothink}

3.2.1 Transported Water: Community Standpipes and/or Household Drinking Water

All 38 transported water samples sites were analyzed for E. coli and coliform bacteria (Escherichia coli and total colifoms, respectively). Analyses were conducted proximal to the sampling sites within 2 hours of collection, with a majority of analyses conducted immediately at the sample site.

Of the 38 collected and analyzed samples, 27 samples tested positive for E. coli with colony numbers ranging between 1 and >200 per $100 \mathrm{~mL}$ sample (Figure 2) and can be classified as Low Risk (Green) to High Risk (Orange) based on Table 1. The average count for E. coli was $42( \pm 22)$ CFU with an average WHO Classification of Intermediate Risk (Yellow). All but 2 of the samples tested positive for total coliforms with a range between 1 and $>200$ colonies, and an average of $69.2( \pm 85.8) \mathrm{CFU}$.

Both E. coli and total coliforms show a weak positive correlation with altitude; however, when the data for the Lukla township is removed there is no correlation (note: Lukla township has a water treatment system discussed in detail below). Similarly, there appears to be no correlation between bacteria counts and $\mathrm{pH}$ and only a very weak correlation between bacteria counts and temperature (Figure 2). Both E. coli and total coliforms show a negative correlation with TDS, particularly E. coli.

In summary, there appears to be little relationship between bacterial counts (E. coli and total coliforms) and both physical parameters and altitude.

\subsubsection{Community Drinking Water Sources}

All 7 community drinking water samples sites were analyzed for E. coli and coliform bacteria (Escherichia coli and Streptococcus faecolies, respectively). Analyses were conducted immediately at the sample site.

Of the 7 collected and analyzed samples, 3 samples contained no E. coli colonies (Khumjung, Namche Bazaar and Phorche), 2 samples contained only 1 colony (Gokyo and Gorek Shep) and 2 samples contained more than 1 colony: Lukla township contained 19 E. coli colonies and Dingboche township contained 60 E. coli colonies (Figure 4). Both those townships were classified Intermediate Risk (Yellow) based on the WHO system (Table 1). All of the community drinking water sources tested positive for total coliforms, except for Khumjung, with a range between 1 colony (Phorche) and >200 colonies in Lukla. The average total coliform count was $33.0( \pm 66.2)$.

There is no correlation between E. coli and any of the physical parameters measured, nor is there a correlation with altitude (Figure 3 ). Total coliforms show a weak negative correlation with altitude and $\mathrm{pH}$ and a weak positive correlation with temperature and TDS.

In summary, there appears to be little relation between bacterial counts (E. coli and total coliforms) and both physical parameters and altitude. 


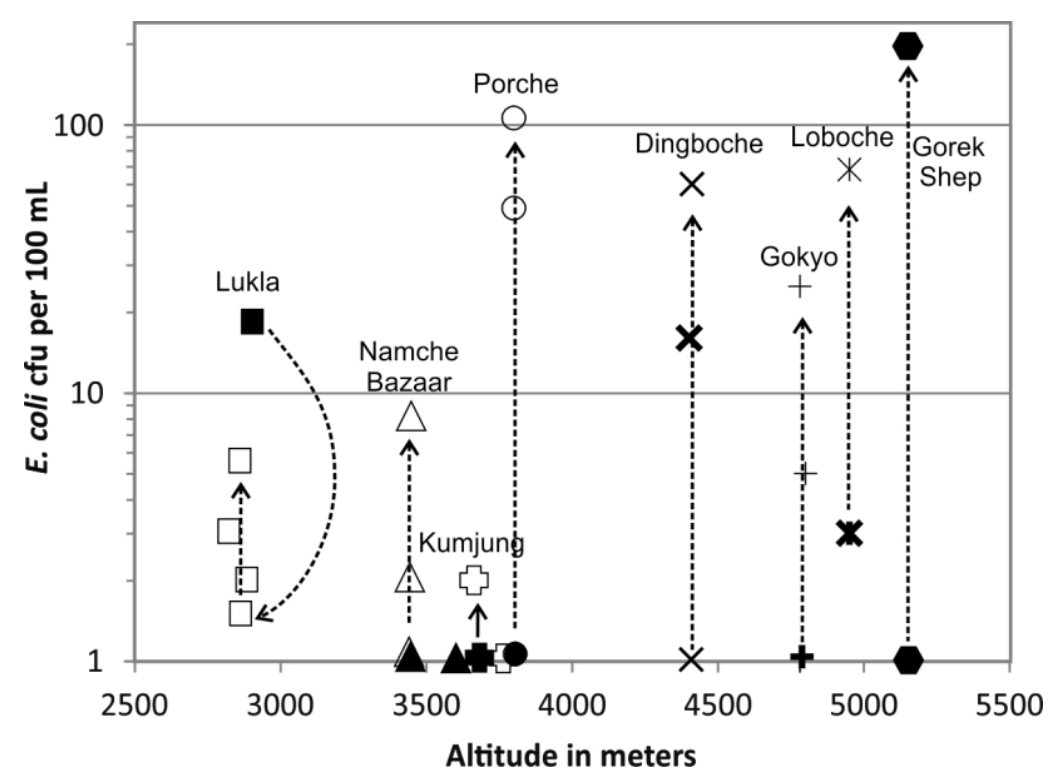

Figure 4. Data from specific villages showing the community drinking water sources (solid or bold) followed by transported water sampled within the same community (i.e. water transported for use in households, teahouses and/or lodges (open and non-bold symbols)). Also shown (solid grey square) is the Lukla community water after passing the township's

filtration system. Note that Lukla is the only community with a water treatment facility

\subsection{Water Handling and Storage}

After sampling and analyses several communities agreed to clean their water holding tanks and allow retesting of the water. Tanks are often used to collect water at or near the source 24 hours per day in order to insure greater availability of water during high use times. Two specific communities/organizations agreed to our request: Phakding and the National Park Service headquarters (based above Namche Bazaar). In both cases the number of colonies decreased. Phakding was only able to clean one of two holding tanks yet the number of colonies dropped from 5 E. coli colonies and >200 total coliform colonies to 2 E. coli colonies and 20 total coliform colonies. The National Park Service headquarters is located above the township of Namche Bazaar and uses the same water source as Namche Bazaar township. After cleaning their holding tanks the number of colonies dropped from $1 \mathrm{E}$. coli colonies and 47 total coliform colonies to 0 E.coli colonies and 4 total coliform colonies.

\section{Discussion}

Physical parameters throughout the study area meet WHO (2011) guidelines. In all samples, there is an increase in $\mathrm{pH}$ with altitude. This could be caused by several factors but the most likely is a change in geology; more carbonates and carbonate bearing minerals are found at higher altitudes (the top of Mt. Everest is limestone; Stöcklin (1980)). Temperature of the community drinking water sources decreased with increasing altitude, as expected. However, the temperature of the transported water did not decrease with increasing altitude. As many samples were transported by black hosepipe, it is likely that the time of day and/or the amount of sunshine on a given day would affect its temperature more than altitude. 
Conductivity and TDS showed no significant correlation with altitude.

The main focus of this research was fecal contamination of drinking water using E. coli as an indirect method to identify contamination by fecal material, which poses significant health risks (WHO 1983; Kistemann et al. 2002; Pathak and Gopal, 2001; Harwood et al. 2001; Vaidya et al. 2001). Findings from the bacterial work showed significant E. coli and coliform contamination in the transported water supplies. E. coli values ranged between 1 and >200 per $100 \mathrm{~mL}$ sample and total coliforms varied between 0 and $>200$ colonies. Related studies include Sharma et al. (2010) and Ghimire et al. (2013a) whose research focused entirely on surface water (rivers and lakes) within the SNP. They concluded that all of the surface water tested contained E. coli and coliform bacteria, with contamination increasing significantly at lower altitudes. Similarly, Baghel et al. (2005) found that bacterial contamination increased from the upper, higher altitude, portion of their study area (the Gangotri glacier (Uttarakhand, India)) to the lower altitude stretches of the Ganges River. The results of Baghel et al. (2005), Sharma et al. (2010) and Ghimire et al. (2013a) suggest that increasing development in anthropogenic and socio-cultural activities in the lower altitude portions of their study areas was responsible for the increased bacterial contamination. Baghel et al. (2005) also found that total coliform and thermotolerant coliforms were at a maximum during summer (followed by monsoon and winter), which the researchers attributed to a larger number of pilgrims and trekkers visiting the area during the summer. Preliminary work by Nicholson et al. (2016) supports the hypothesis that contamination of drinking water is higher at lower altitudes and possibly related to tourist and/or residential population.

Our results are complimentary to those of Baghel et al. (2005), Sharma et al. (2010), Ghimirie et al. (2013a,b) and Nicholson et al. (2016): we see a correlation between bacterial counts and altitude in community drinking water sources. However, we see no direct correlation between bacterial contamination and altitude in transported water. The largest low-altitude towns (Lukla, Namche Bazaar, Porche and Khumjung) have the highest density of both residents and tourists, yet our coliform bacteria and E. coli data suggest that although fecal contamination of community drinking water sources may be related to population, the contamination of transported water is not.

The results of this work indicate that for many communities their drinking water sources are relatively uncontaminated by fecal matter and considered Low Risk by WHO (2011) standards. The exceptions are Dingboche and Lukla, both of which have community drinking water sources with High and Intermediate Risk levels, respectively (WHO 2011). Both townships use a mixture of spring and surface water that is transported and held in storage tanks prior to use. When considering data from community standpipes, households, teahouses, lodges and restaurants (transported water), there is a noticeable increase in both fecal contamination indicators (specifically E. coli) and total coliforms. Figure 4 shows the 7 communities where the community drinking water source is compared to transported water from the same community. In all cases, except for Lukla, the number of E. coli and total coliforms increased away from the original community drinking water source. Hence, it is likely that water transportation and handling is more of a problem in these communities than contamination of the original source water. One sample from Dingboche showed a decrease 
in E. coli after transportation from the source. This sample had a temperature of $37 \mathrm{oC}$ and was taken from a black hose that was exposed to the elements (in this case sunshine) for approximately $0.5 \mathrm{~km}$. We suggest that during the middle of the day this water gets hot enough to kill the bacteria. Please note that bacterial colonies can fluctuate dramatically and that more work is needed before we can declare the community water sources as "safe" (e.g., In Conformity or Low Risk).

A comprehensive overview of published literature dealing with fecal contamination and water handling practices by Wright et al. (2004) suggests that our findings are similar to studies from other developing nations. Wright et al. (2004) reviewed 57 published studies specifically focused on household water contamination between source and point-of-use to identify how water contamination varies between the different study settings. They conclude that bacteriological quality of drinking water significantly declines after collection/storage/transportation in many settings and, importantly, that the extent of contamination after water collection is proportionately greater where fecal and total coliform counts in source water are low (Wright et al. 2004). Other studies, such as Trevett et al. (2005) and Eschol et al. (2009), have shown conclusively that post-collection water handling and storage significantly increases bacteria counts in drinking water. In particular, both studies have shown that plastic water collection containers are prone to contamination, and that fecal contamination on individuals' hands (Trevett et al. 2005) also plays a key role in drinking water contamination. As such, in addition to consideration of drinking water source contamination, there needs to be consideration of water collection, handling and transportation (hence known as "water-handling practices") within the SNP and SNP Buffer Zone.

The township of Lukla is an excellent example where water-handling practices are a problem. Lukla township has a community water board and has built a water treatment plant. The water treatment plant is an open filtration system using locally sourced sand and gravel. This water serves as both the community drinking water and the community fire services supply. In Lukla the community drinking water source contained 18 E. coli colonies and over 200 total coliform colonies before treatment. Immediately after filtration, the community water contained 1-3 E. coli colonies and $\sim 70$ total coliform colonies. Hence their sand/gravel filtration system takes their water from being in the WHO (2011) category of Intermediate Risk and reduces it to Low Risk. However, further sampling of users downstream show an increase in contamination (Figure 4), supporting the argument that water-handling practices need to be addressed.

Even though changes in water-handling practices (such as cleaning of tanks and hoses) may reduce drinking water contamination in the SNP and SNP Buffer Zone, this does not address the underlying problem of contaminated source water in villages, such as Lukla and Dingboche, or what may occur in the rainy season. We recognize that non-chlorinated community water supplies may become polluted when contaminated surface water mixes with the drinking water during the monsoons. Unmanaged and/or poorly managed solid waste disposal and open defecation throughout the SNP has (and is) resulted in contamination of the major rivers (Ghimire et al. 2013). Raw sewage and toilet waste in many communities is 
piped directly into nearby streams and rivers (authors' personal observations; Carovello et al. 2007). In order to ensure long-term sustainability, the World Tourism Organization (WTO) states that tourism operations in protected areas need to be carefully planned, managed and monitored. The residents of the SNP and SNP Buffer Zone depend on tourism and realize that improving environmental standards in the region are key to sustaining their tourist industry. However, this is difficult given the complicated system of management and governance in the SNP and SNP Buffer Zone.

The management of the SNPs drinking water quality, sewage and waste, has devolved in recent years from the national government to citizens and communities across Nepal, including the SNP and SNP Buffer Zone. Initially, in 1976 the state had control of most resources and tourism revenues through the Park Management Plan (Garratt 1981). However, the national government was unable to effectively support, maintain, and monitor environmental standards, hence the Buffer Zone Policy was created in 2002. The Buffer Zone Policy allocates $30-50 \%$ of park revenues for investment in local development and encourages increased community-based management of resources. The recently redeveloped Park Management Plan (DNPWC 2005, 2006) emphasizes community self-governance and support of local economic development (Daconto and Sherpa, 2010). Ideally, this framework should allow the public and community groups to play an integral part of the development and operation of community based governance and management plans (Acharya 2015).

\section{Conclusions}

During the dry season, our study shows that:

A) Drinking water within the SNP region meets current WHO (2011) drinking water standards for the physical properties of $\mathrm{pH}$, temperature, conductivity, and TDS.

B) Community drinking water sources, collected at or near the first point of use, were generally "Low Risk" by WHO (2011) standards.

C) Water that was transported in hoses or stored in holding tanks were generally considered to be "Intermediate to High Risk" by WHO (2011) standards, suggesting that better water-handling practices are needed throughout the region.

D) This study provides a baseline dataset for future monitoring and allows for comparison for water supplies improvement and/or monsoon sampling.

E) There appears to be little or no relationship between physical parameters and bacteria content.

These results clearly indicate that there is a need for improved water storage, handling and transportation methods. Future studies must focus on working within communities to develop better water management strategies and foster community driven, sanitation focused, education initiatives. Combined, improved water testing, education and management could potentially solve the problem of contaminated drinking water within the SNP and SNP Buffer Zone and help support increased tourism. 


\section{Acknowledgements}

The authors would like to thank the following people and organizations for their support: Troy Risk Inc. (Indianapolis), Indiana Geologists, Ball State University, Ang Norbu Sherpa (Holiday Namche), Ang Pema Sherpa (Valley View Khumjung) and the Sagarmatha National Park Service.

\section{References}

APHA (2005). Standard Method for the Examination of Water and Wastewater, 21st ed. American Public Health Association, Washington DC.

APHA (1998). Standard Method for the Examination of Water and Wastewater, 19th ed. American Public Health Association, Washington DC.

Baghela, V. S., Gopalb, K., Dwivedia, S., \& Tripathi, R. D. (2005). Bacterial indicators of faecal contamination of the Gangetic river system right at its source, Ecological Indicators, 5, 49-56. https://doi.org/10.1016/j.ecolind.2004.09.002

Balestrini, R., Polesello, S., \& Sacchi, E. (2014). Chemistry and isotopic composition of precipitation and surface waters in Khumbu valley (Nepal Himalaya): $\mathrm{N}$ dynamics of high elevation basins, Science of the Total Environment, 485, 681-692.

https://doi.org/10.1016/j.scitotenv.2014.03.096

Cairneross, S., Carruthers, I., Curtis, D., Feachem, R., Bradley, D., \& Baldwin, G. (1980). Evaluation for Village Water Supply Planning. Wiley, Chichester, p. 277.

Caravello, G. U., Boselli, A. M., Bertollo, P., \& Baroni, A. (2007). Assessing Ecosystem Health: An Analysis of Tourism Related Change and Impact in Khumbu Valley, International Journal of Ecology, 14, 45-64.

Central Bureau of Statistics - National Planning Commission (2001) Nepal - National Population Census 2001, Tenth Census, http://cbs.gov.np/nada/index.php (accessed September 2016).

Eshcol, J., Mahapatra, P., \& Keshapagu, S. (2009) Is fecal contamination of drinking water after collection associated with household water handling and hygiene practices? A study of urban slum households in Hyderabad, India. Journal of Water and Health, 7, 145-154. https://doi.org/10.2166/wh.2009.094.

Gameson, A. L. H., \& Saxon, J. R. (1967). Field studies on effect of daylight on mortality of coliform bacteria, Water Research, 1, 279-295.

https://doi.org/10.1016/0043-1354(67)90004-8

Ghimirie, N. P., Jha, P. K., \& Caravello, G. (2013a). Physico-Chemical Parameters of High-Altitude Rivers in the Sagarmatha (Everest) National Park, Nepal, Journal of Water Resource and Protection, 5, 761-767. https://doi.org/10.4236/jwarp.2013.58077

Ghimirie, N. P., Jha, P. K., \& Caravello, G. (2013b). Water Quality of High-Altitude Lakes in the Sagarmatha (Everest) National Park, Nepal, Journal of Environmental Protection, 4, 
22-28. https://doi.org/10.4236/jep.2013.47A003

Gruver, J., Nicholson, K. N., Neumann, K., Sharma, S., \& Dowling, C., (2017). Water quality in the Sagarmatha National Park, Nepal: A modification of viable field-based testing methods. Environmental Management and Sustainable Development, 6, 361-372.

https://doi.org/10.5296/emsd.v6i2.10635

Harwood, V. J., Brownell, M., Perusek, W., \& Whitelock, J. E. (2001). Vancomycin-resistant enterococcus sp. Isolated from waste water and chicken feces in the United States. Applied Environmental Microbiology, 67, 4930-4933.

https://doi.org/10.1128/AEM.67.10.4930-4933.2001

Hodegkiss, I. J. (1988). Bacteriological monitoring of Hong Kong marine water quality. Environment International, 14, 495-499. https://doi.org/10.1016/0160-4120(88)90410-2

Karkey, A., Jombart, T., Walker, A. W., Thompson, C. N., Torres, A., Dongol, S., et al. (2016) The Ecological Dynamics of Fecal Contamination and Salmonella Typhi and Salmonella Paratyphi A in Municipal Kathmandu Drinking Water. PLoS Neglected Tropical Diseases, 10(1), e0004346 https://doi.org/10.1371/journal.pntd.0004346

Kistemann, T., Claben, T., Koch, C., Dangendorf, F., Fischeder, R., Gebel, J., Vacata, V., \& Exner, M. (2002). Microbial load of drinking water reservoir Tributaries during extreme rainfall and runoff. Applied Environmental Microbiology, 68, 2188-2197.

https://doi.org/10.1128/AEM.68.5.2188-2197.2002

McLellan, S. L., Daniels, A. D., \& Salmore, A. K. (2001). Clonal populations of thermotolerant enterobacteriaceaes in recrea- tional water and their potential interference with fecal Escherichia coli counts. Applied Environmental Microbiology, 67, 4934-4938.

https://doi.org/10.1128/AEM.67.10.4934-4938.2001

Nicholson, K. N., Hayes, E., Neumann, K., \& Dowling, C., 2016, Drinking water quality in the Sagarmatha National Park (Mt. Everest) Nepal. Journal of Geoscience and Environment Protection, 4, 43-53. https://doi.org/10.4236/gep.2016.44007

Okpokwasili, G. C., \& Akujobi, T. C. (1996). Bacteriological indicators of tropical water quality. Environmental Toxicology, 11, 77-81.

https://doi.org/10.1002/(SICI)1098-2256(1996)11:2<77::AID-TOX1>3.0.CO;2-5

Pathak, S. P., \& Gopal, K. (2001). Rapid detection of Escherichia coli as an indicator of faecal pollution in water. Indian Journal of Microbiology, 41, 139-151.

Salerno, F., Viviano, G., Thakuri, S., Flury, B., Maskey, R. K., ... Manfredi, E. C. (2010a). Energy, forest, and indoor air pollution models for Sagarmatha National Park and Buffer Zone, Nepal: implementation of a participatory modeling framework. Mountain Resource Development, 30(2), 113e126.

Salerno, F., Cuccillato, E., Caroli, P., Bajracharya, B., Manfredi, E. C., Viviano, G., Thakuri, S., Flury, B., Basani, M., Giannino, F., \& Panzeri, D. (2010b). Experience with a hard and soft participatory modeling framework for social-ecological system management in Mount 
Everest (Nepal) and K2 (Pakistan) protected areas. Mountain Resource Development, 30(2), $80 \mathrm{e} 93$.

Salerno, F., Viviano, G., Manfredi, E. C., Caroli, P., Thakuri, S., \& Tartari, G. (2013). Multiple Carrying Capacities from a management-oriented perspective to operationalize sustainable tourism in protected areas. Journal of Environmental Management, 128, 116-125. https://doi.org/10.1016/j.jenvman.2013.04.043

Sood, A., Singh, K. D., Pandey, P., \& Sharma, S. (2008). Assessment of bacterial indicators and physicochemical parameters to investigate pollution status of Gangetic river system of Uttarakhand (India), Ecological Indicators, 8, 709-717.

https://doi.org/10.1016/j.ecolind.2008.01.001

Sharma, C. M., Sharma, S., Gurung, S., Jutther, I., Bajracharya, R. M., \& Pradhan, N. S. (2010). Ecological studies with the Gokyo wetlands, Sagarmatha National Park, Nepal. Contemporary Research in Sagarmatha (Mt. Everest) Region, Nepal (An Anthology). Eds. P K Jha and I Khanal, Publ. Nepal Academy of Science and Technology, Kathmandu. pp: 139-154.

Stöcklin, J. (1980). Geology of Nepal and its regional frame. Journal of the Geological Society of London, 137, 1-34. https://doi.org/10.1144/gsjgs.137.1.0001

Trevett, T., Carter, R., \& Tyrell, S. (2005) Mechanisms leading to post-supply water quality deterioration in rural Honduran communities. International Journal of Hygiene and Environmental Health, 208, 153-161. https://doi.org/10.1016/j.ijheh.2005.01.024

Viviroli, D., Archer, D. R., Buytaert, W., Fowler, H. J., Greenwood, G. B., ... Woods, R. (2011). Climate change and mountain water resources: overview and recommendations for research, management and policy, Hydrology and Earth System Science, 15, 471-504, https://doi.org/10.5194/hess-15-471-2011

Vaidya, S. Y., Vala, A. K., \& Dube, H. C. (2001). Bacterial indicators of faecal pollution and Bhavnagar Coast. Indian Journal of Microbiology, 41, 37-39.

World Health Organization [WHO] (1983) Guidelines for Drinking Water Quality, vol. 3. World Health Organization, Geneva.

WHO (2011). "Guidelines for Drinking Water Quality" [Electronic Resource]: Fourth Edition, World Health Organization, Geneva, p. 541.

WHO (2008). "Guidelines for Drinking Water Quality [Electronic Resource]: Third Edition, Incorporating the First and Second Addenda, Volume 1, Recommendations," World Health Organization, Geneva, p. 668.

WTO [World Tourism Organization] (2005). Tourism's Potential as a Sustainable Development Strategy. World Tourism Organization, Madrid, Spain.

Wright, J., Gundry, S., \& Conroy, R. (2004) Household drinking water in developing countries: a systematic review of microbiological contamination between source and 


\section{Macrothink \\ Environmental Management and Sustainable Development \\ ISSN 2164-7682 \\ 2017, Vol. 6, No. 2}

point-of-use. Tropical Medicine and International Health, 9, 106-117.

https://doi.org/10.1046/j.1365-3156.2003.01160.x

\section{Copyright Disclaimer}

Copyright for this article is retained by the author(s), with first publication rights granted to the journal.

This is an open-access article distributed under the terms and conditions of the Creative Commons Attribution license (http://creativecommons.org/licenses/by/3.0/). 